\title{
Two-Scale Investigation of the Retention Behavior of a Well-Graded Mixed Soil
}

\author{
Osvaldo Bottiglieri * ${ }^{\mathbb{D}}$, Francesco Cafaro and Federica Cotecchia
}

check for updates

Citation: Bottiglieri, O.; Cafaro, F.;

Cotecchia, F. Two-Scale Investigation of the Retention Behavior of a Well-Graded Mixed Soil. Geosciences 2021, 11, 431. https://doi.org/ 10.3390/geosciences 11100431

Academic Editors:

Jesus Martinez-Frias and Meng Lu

Received: 27 September 2021

Accepted: 14 October 2021

Published: 18 October 2021

Publisher's Note: MDPI stays neutral with regard to jurisdictional claims in published maps and institutional affiliations.

Copyright: (c) 2021 by the authors. Licensee MDPI, Basel, Switzerland. This article is an open access article distributed under the terms and conditions of the Creative Commons Attribution (CC BY) license (https:/ / creativecommons.org/licenses/by/ $4.0 /)$.
DICATECH, Politecnico di Bari, Via Edoardo Orabona 4, 70125 Bari, Italy; francesco.cafaro@poliba.it (F.C.); federica.cotecchia@poliba.it (F.C.)

* Correspondence: osvaldo.bottiglieri@poliba.it

\begin{abstract}
The hydraulic characterization of mixed compacted soils is helpful for the design of earthworks subjected to drying-wetting cycles. When the mixed soil is well-graded and made of both coarse and fine fractions, its matric suction may also be due to the short-range adsorption phenomena, as for the soil investigated in this research work. A silty-clayey sand was created by a mixing procedure and experimentally investigated at two different scales. Physical modeling of an infiltration process was performed, allowing an inverse numerical analysis to infer the water retention and the hydraulic conductivity functions of the soil, whereas element testing on soil specimens allowed direct determination of the same equations. In the article, problems related to the employed suction measurement techniques have been pointed out and discussed. By this two-scale combined strategy, features of the soil hydraulic behavior, such as the wetting collapse, the shrinkage during drying, and the loop of hysteresis, were also determined.
\end{abstract}

Keywords: water retention curve; matric suction; physical modeling; hysteresis; collapse

\section{Introduction}

The hydraulic characterization of mixed compacted soils is relevant to the design of earthworks subjected to imbibition-evaporation cycles (e.g., dams and embankments), since the changes in the suction profiles within the soil affect its stress-strain response and, therefore, work safety and serviceability. When the mixed soil is well-graded and made of both coarse and a fine fractions, different physical-chemical phenomena are involved in the solid-fluid interaction during the wetting and drying processes. In particular, the matric suction, that is the component of the total suction pertaining to the soil skeleton, arises from two distinct sources: capillary and short-range adsorption phenomena. The first source is controlled by the pore size density distribution [1,2]. The importance of the second one increases with an increase in the amount of silty and clayey fractions present in the soil. Moreover, the short-range adsorption effects become relevant at relatively low water content, when the adsorbed pore water is in the form of thin films coating the particle surface [3]. Not all the devices generally employed for the matric suction measurement can detect both components; that is the reason why a good characterization of the retention properties of a well-graded soil should be carried out by means of multiple measurement techniques.

The soil investigated in this study is a silty-clayey sand. Its water retention function has been deduced through experimental tests carried out at two different scales. A physical infiltration process [4] through a large soil volume has been performed, and an inverse numerical analysis of such boundary value problems has revealed the hydraulic equations of the porous medium, i.e., both the water retention, WRC, and hydraulic conductivity, and $\mathrm{k}(\mathrm{s})$ functions $[5,6]$. These functions represent the constitutive laws to be implemented in the analysis of seepage through a partially saturated soil domain. At the element volume scale, the soil retention properties have been investigated through laboratory testing on soil specimens. At both scales, the initially dry soil was subjected to a wetting path, followed 
by a drying path. Its hydraulic response is interpreted in this paper according to the framework of the hydraulic history, conceptualized by Lukner [7] for coarse-textured soils, and is shown in Figure 1. The figure shows the possible hydraulic paths experienced by the soil represented in the volumetric water content vs. suction plot, which configures options for the hysteresis loops.

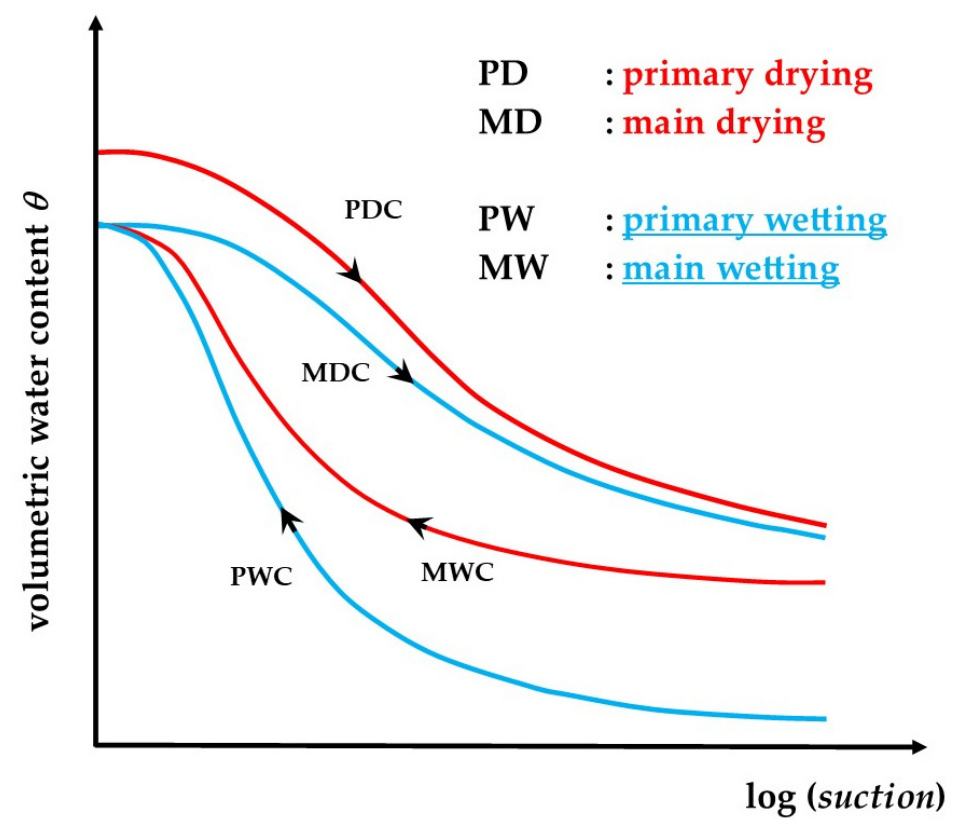

Figure 1. The framework of soil hydraulic histories (adapted from [7]).

The two possible virgin paths, either under drying or under wetting, are identified as "primary" paths. Therefore, adopting the terminology in Figure 1, during the experimental investigation, the virgin compacted soil was subject to primary wetting; thereafter, its state moved along the main drying branch. The two-scale investigation allowed both to employ different techniques of suction measurement for a more reliable determination of the WRC over a wide suction range and to better understand how the soil's volumetric collapse [8-10] occurs due to moisture variations at different confining stresses. During the laboratory element volume tests, the discrepancy between matrix and total suction (attributable to the osmotic suction component, which depends on the pore fluid composition) has also been assessed.

The water retention curve has been formalized using the model proposed by van Genuchten [11]. Regarding the hydraulic conductivity function k(s), due to the difficulties to measure it directly, the water retention model can be combined with capillary models, e.g., those by Mualem [12], Burdine [13], and Fatt and Dykstra [14], leading to different conductivity expressions [15]. In this work, the Mualem model has been adopted. From an experimental point of view, it is common practice to obtain the hydraulic conductivity function of porous media by physical modeling during flow in a column of unsaturated material, monitoring the transient process either by TDR probes [16] or by tensiometers [17] located at different depths (i.e., monitoring either water content or suction profiles).

It is worth noting that the van Genuchten model assumes that the volumetric water content, $\theta_{0}$, at which matric suction is zero, corresponds to a degree of saturation equal to $100 \%\left(\theta_{0}=\theta_{\mathrm{s}}\right.$, where $\theta_{\mathrm{s}}$ is the volumetric water content at saturation). This is an ideal behavior that is intermediate between that of swelling soils recovering full saturation at negative pore pressures [18] and that of soils needing positive pore pressures to be fully saturated, for which suction disappears at relatively low saturation degrees, i.e., right, and left of the intermediate behavior ([19]; Figure 2; Table 1). This last behavior, due to air entrapment upon wetting, is typical of coarse-grained soils [20-22] but it has also been observed for fissured natural clays [23]. In the following, the retention behavior of the 
mixed soil under study will also be discussed in light of the frameworks presented in both Figures 1 and 2.

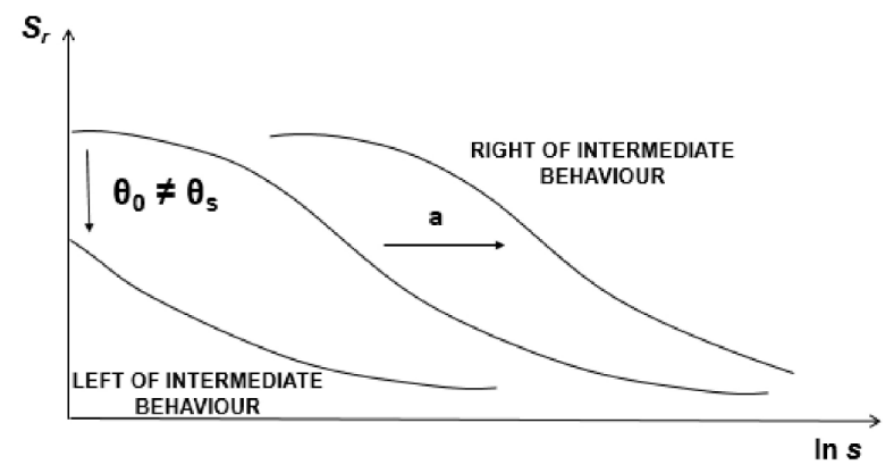

Figure 2. A possible framework for porous media under wetting [19], in the Saturation Degree vs. Suction plot: the arrow pointing right indicates that van Genuchten's parameter "a" increases, together with the Air Entry Value; the arrow pointing down indicates that $\theta_{0} \operatorname{can}$ be lower than $\theta_{\mathrm{s}}$.

Table 1. Values of the saturation degree when suction practically disappears for porous materials under wetting.

\begin{tabular}{cc}
\hline Materials & Saturation Degree \\
\hline SILTY SAND [24] & $70 \%$ \\
\hline PERVIOUS CONCRETE [19] & $30 \%$ \\
\hline MEDIUM COARSE SAND [22] & $80 \%$ \\
\hline
\end{tabular}

\section{Materials and Methods}

\subsection{Soil Composition and State after Compaction}

The soil was obtained by mixing a fine-grained soil with a coarse-grained one. The finer component, S1 from now on, is a natural illitic clayey soil, part of the Subappennine Blue Clays. About 1 ton of this soil was sampled on the right bank of the Abate Alonia basin (Potenza, Italy; [25]). The soil was then dumped in the lab and subjected to cleaning by hand to remove the coarser grains and macroscopic organic components. The soil was dried by means of a UV ray lamp and a fan until a hygroscopic water content was achieved. A final stage of breaking up by electric mill made it possible to remove all the clods of clay. The grain size distribution of S1 is reported (dash-dot line) in Figure 3. The measured liquid and the plastic limits equal 55 and 27\%, respectively; accordingly, S1 can be classified as $\mathrm{CH}$ according to USCS-ASTM (2006). The specific gravity of S1 was measured as $\mathrm{Gs}=2.72$.

The coarser soil component, in the following denoted as S2, is a clean quartz sand. The specific gravity of $\mathrm{S} 2$ was $\mathrm{Gs}=2.50$. Its grain size distribution is reported (dashed line) in Figure 3; it is a uniform medium sand, SP according to USCS. S2 was stored in a dry place to achieve its hygroscopic water content. The mixing of the two soil components led to a prototype soil, PS, made up (in weight) of $30 \%$ of S1 and $70 \%$ of S2. About 1.5 tons of this mixture was created using a laboratory concrete mixer. The resulting particle size distribution is shown in Figure 3, and the specific gravity was found to be Gs $=2.649$.

The soil PS was then subjected to standard Proctor compaction tests (Figure 4), which allowed to determine the optimum moisture content equal to $10 \%$, and the maximum dry unit weight, equal to $19.8 \mathrm{kN} / \mathrm{m}^{3}$, which corresponds to a void ratio $\mathrm{e}=0.318$. 


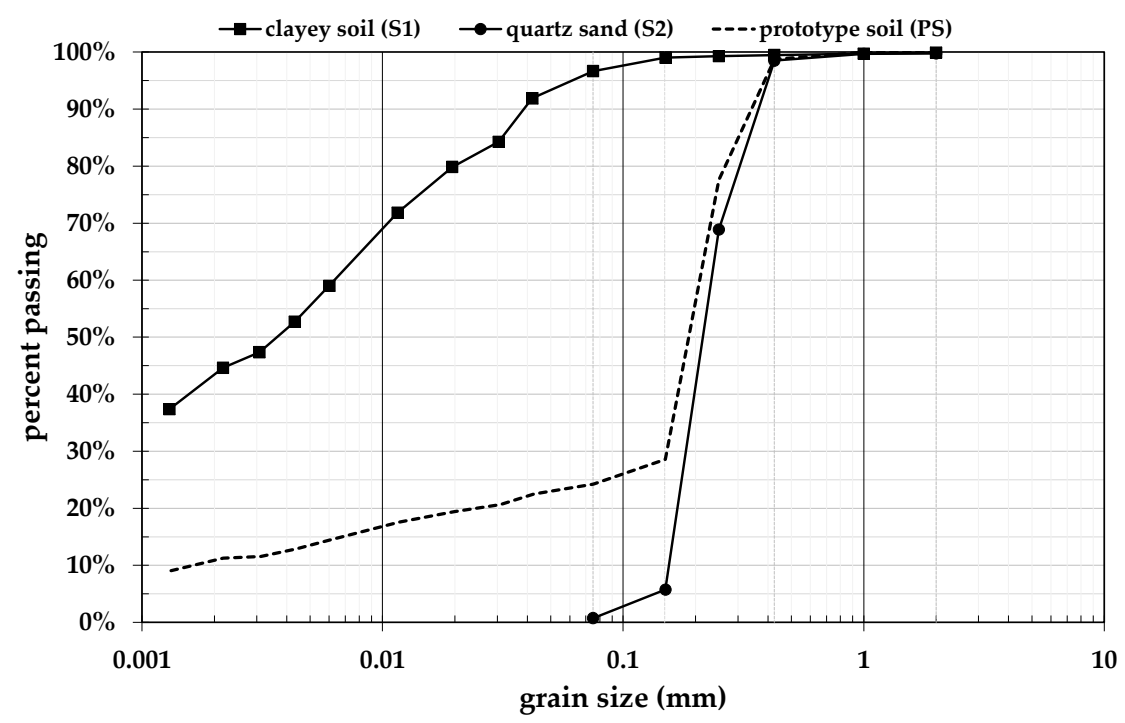

Figure 3. Grain size distribution of the materials under study: S1 (clayey soil); S2 (quartz sand); PS (prototype soil).

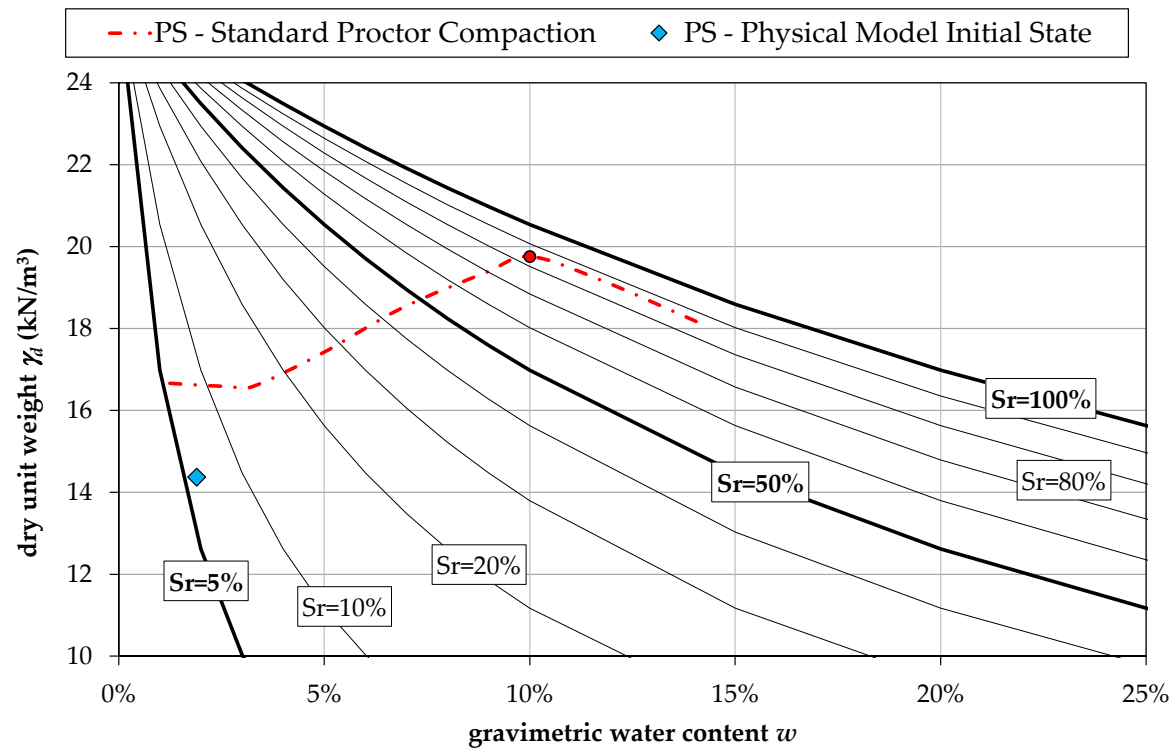

Figure 4. Curve from standard Proctor compaction test of PS (prototype soil) compared to its initial state.

\subsection{Experimental Set Up}

As anticipated in the Introduction, the investigation of the soil hydraulic properties was carried at two scales. At the finite scale, to compute an inverse analysis of the data and deduce the soil's constitutive parameters, an infiltration process through the soil in a physical model was monitored. Both the soil WRC and $\mathrm{k}(\mathrm{s})$ controlling seepage have been derived by the inverse analysis of the logged data through the use of the Levenberg-Marquardt algorithm [26,27]. At the element volume scale, the soil state during wetting-drying tests has been measured using both an ad hoc designed experimental device, and a conventional oedometer apparatus. An image of the physical model [8], is shown in Figure 5. It consists of a stainless-steel tank of inner volume: $1 \mathrm{~m}$ length $\times 2 \mathrm{~m}$ base $\times 0.5 \mathrm{~m}$ height. One of the lateral sides, made of perspex, was transparent to allow visual inspection of the wetting front during infiltration stages that were generated using irrigation sprinkler devices with a calibrated water supply, while the drying process was induced by vapor lamps. The tank was inclined by $7 \%$, in order to determine a plane seepage domain, rather than a one-dimensional one. 


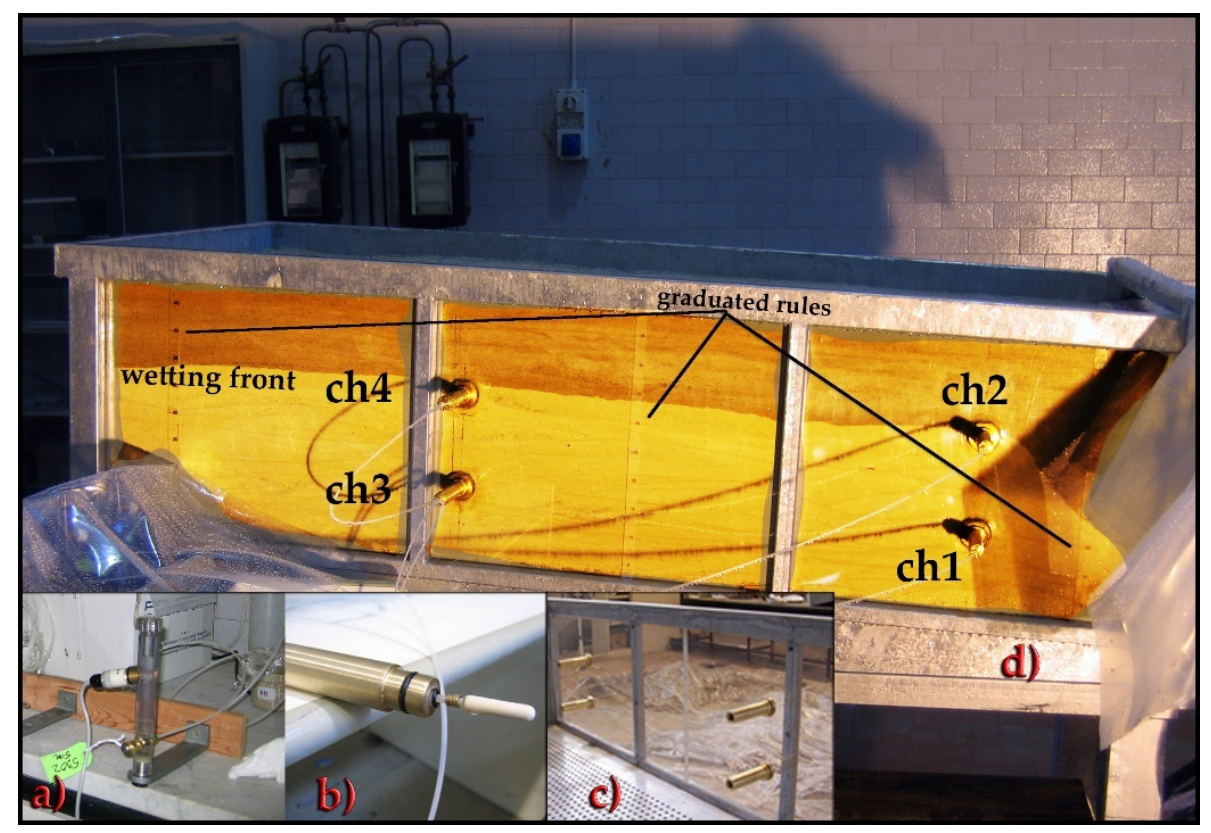

Figure 5. Physical model apparatus: (a) remote positioning tensiometer; (b) handles for the insertion of ceramic tips; (c) tubes for the tensiometers ceramic tips handles; (d) transparent tank side with three graduated rules for the tracing of the wetting front and channel map of the tensiometers in the data acquisition system.

The perspex side of the tank was equipped with four $2100 \mathrm{~F}$ remote positioning tensiometers (Figure 5a), manufactured by the Soilmoisture Equipment Corp. They could work in the 0-100 kPa matric suction range [28]. As shown in the Figure, the tensiometers could be inserted into the soil layer in pairs on two adjacent verticals (Figure $5 \mathrm{c}, \mathrm{d}$ ). Four cylindrical metal handles (Figure $5 b, c$ ) were designed to ensure contact between the tensiometer ceramic tip and the soil, far enough from the tank side, in order to minimize the end effects on the suction measurements. The bottom base of the tank as well as the downstream edge (with respect to the tank slope) were provided by a stainless-steel grid, to ensure a free drainage boundary condition. The plates were coated with geotextile to prevent soil loss. The prototype soil was settled in the tank layer by layer, each $5 \mathrm{~cm}$ thick. At every filling stage, the weight and then the water content of the employed soil stratum was measured, whose sum and average provided, respectively, the total weights and the moisture content across the physical model in the initial conditions. Each layer, once pluviated, was very mildly compacted in order to assign a flat top surface, before being buried and compressed under the upper layers. The tank volume $\left(1 \mathrm{~m}^{3}\right)$ and, therefore, the soil settled inside it, together with its total weight, mean moisture content, and specific gravity Gs, made it possible to estimate the initial soil state across the physical model. Table 2 reports the average initial state of the model soil in terms of dry unit weight, $\gamma_{d}$, gravimetric water content, $\mathrm{w}_{\mathrm{i}}$, void ratio, $\mathrm{e}_{\mathrm{i}}$, saturation degree, $\mathrm{Sr}$, and volumetric water content, $\theta_{\mathrm{i}}$.

Table 2. Soil average initial state of PS after its setup in the tank.

\begin{tabular}{ccccccc}
\hline $\mathbf{G}_{\mathbf{s}}$ & $\gamma_{\mathbf{d}}\left(\mathbf{k N} / \mathbf{m}^{3}\right)$ & $\mathbf{w}_{\mathbf{i}}(\mathbf{\%})$ & $\mathbf{e}_{\mathbf{i}}$ & $\mathbf{n}_{\mathbf{i}}$ & $\operatorname{Sr}(\mathbf{\%})$ & $\theta_{\mathbf{i}}$ \\
\hline 2.649 & 14.3 & 1.44 & 0.81 & 0.45 & 4.7 & 0.021 \\
\hline
\end{tabular}

At the accomplishment of the filling, four samples were taken at different depths of the stratum to assess the vertical profile of the soil void ratio. As shown in Figure 6, the void ratio, $\mathrm{e}_{0}$, was found to vary in a quite narrow range, giving evidence of a substantial uniform degree of compaction of the soil in the physical model. 


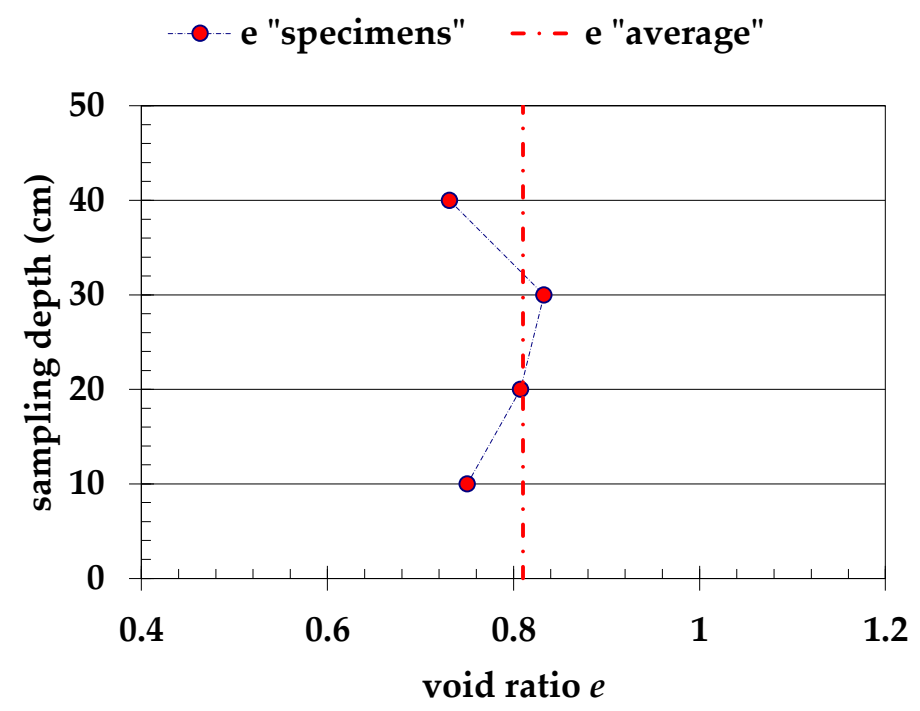

Figure 6. Vertical profile of the voids ratio and its average value within the physical model.

The numerical simulation of the process has been carried out by means of Hydrus2D [29], a numerical code that solves Richard's equation [30] to simulate water flow in variably saturated subsurface media using the finite-element method (FEM).

As said before, in the experimental program the direct measurement of the WRC was also performed using a device ([4,31]; Figure $7 \mathrm{a}, \mathrm{b})$ designed on purpose.

The device (Figure $7 \mathrm{a}, \mathrm{b}$ ) is a transparent perspex cylinder able to host a soil sample of diameter $55 \mathrm{~mm}$ and height variable in a range $100 \mathrm{~mm}-110 \mathrm{~mm}$; the logging of the current specimen height can be made by visual reading. The specimen is delimited by a pair of aluminum pins that, thanks to screwable flanged pvc caps, can slide without rotation inside the cell, so allowing to manually adapt the inner cell volume to that of the soil specimen if it changes during wetting-drying cycles. Open valves through the caps ensure atmospheric pressure of the air $\left(u_{g}=0\right)$ inside the cell and prevent axis translation effects, so that only the water pressure component, $u_{w}$, contributes to changes in suction $\left(\underline{s}=u_{a}-u_{w}\right)$. The matric suction is directly and continuously measured by two low capacity tensiometers (Figure 7a,b), such as those adopted in the physical model. Furthermore, at both ends of the device, it is possible to locate paper discs for indirect measurement of suction through filter paper method technique by "in contact filter paper method (i.c.f.p.m.)" or "not in contact filter paper method (n.i.c.f.p.m.)" depending on whether the matric or total suction is to be measured. The device is placed on a precision lab scale to continuously measure the specimen weight. The volumetric water content of the specimen results from the combination of the measurements of its volume and weight. The whole apparatus is inside a protective perspex case. (Figure $7 \mathrm{~b}$ ). Each specimen was prepared using the PS soil damped in the apparatus to reach the same initial gravimetric water content and density as the average ones of the soil in the physical model. 


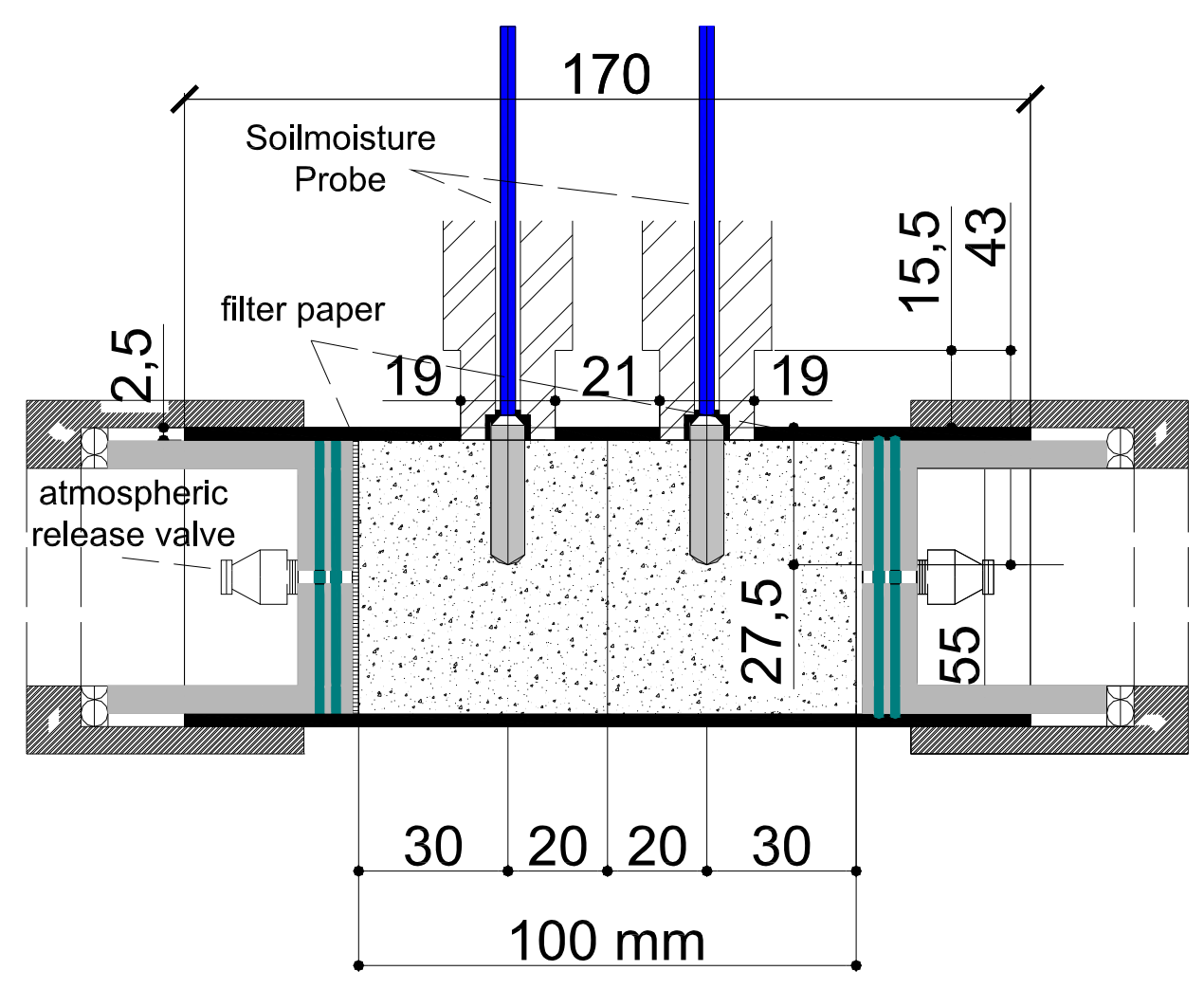

(a)

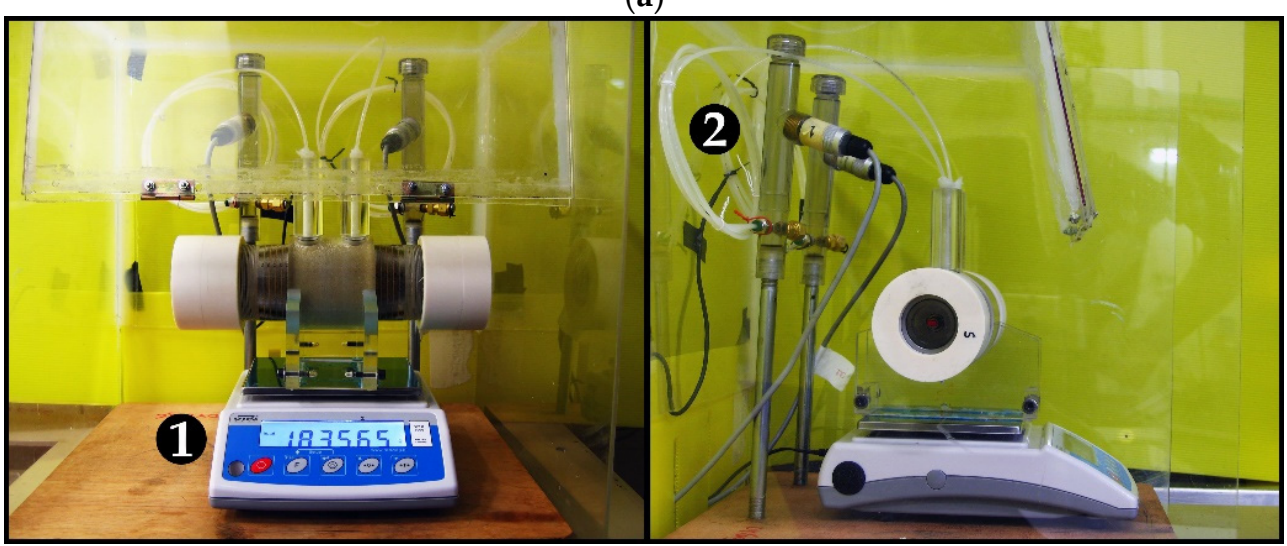

(b)

Figure 7. (a) Design of the experimental device for the investigation of hydraulic retention properties at element volume scale. (b) Actual working setup of the experimental device: (1) precision lab scale connected by RS232 to the data acquisition system for the continuous monitoring of the sample weight; (2) PT2 probe for temperature monitoring inside the isolation case.

\section{Retention Behavior under Wetting}

\subsection{Wetting Branch of the WRC Deduced from the Physical Model Data}

The prototype soil was deposited in the physical model according to the procedure outlined before and, thereafter, the distribution of the suction across the model soil was logged by means of the Soilmoisture tensiometers shown in Figure 5. After the insertion of the tensiometers in the physical model, we measured matric suctions in the range $60-63 \mathrm{kPa}$ after $24 \mathrm{~h}$ equalization time. Thereafter, infiltration through the top boundary of the model was activated by applying a first artificial rainfall, held for $4 \mathrm{~h}$, at an intensity of $15 \mathrm{~mm} / \mathrm{h}$. Figure 8 shows the position of the wetting front along three equally spaced graduated rules, at eight times $t_{i}$ since the beginning of the first artificial rainfall event. 


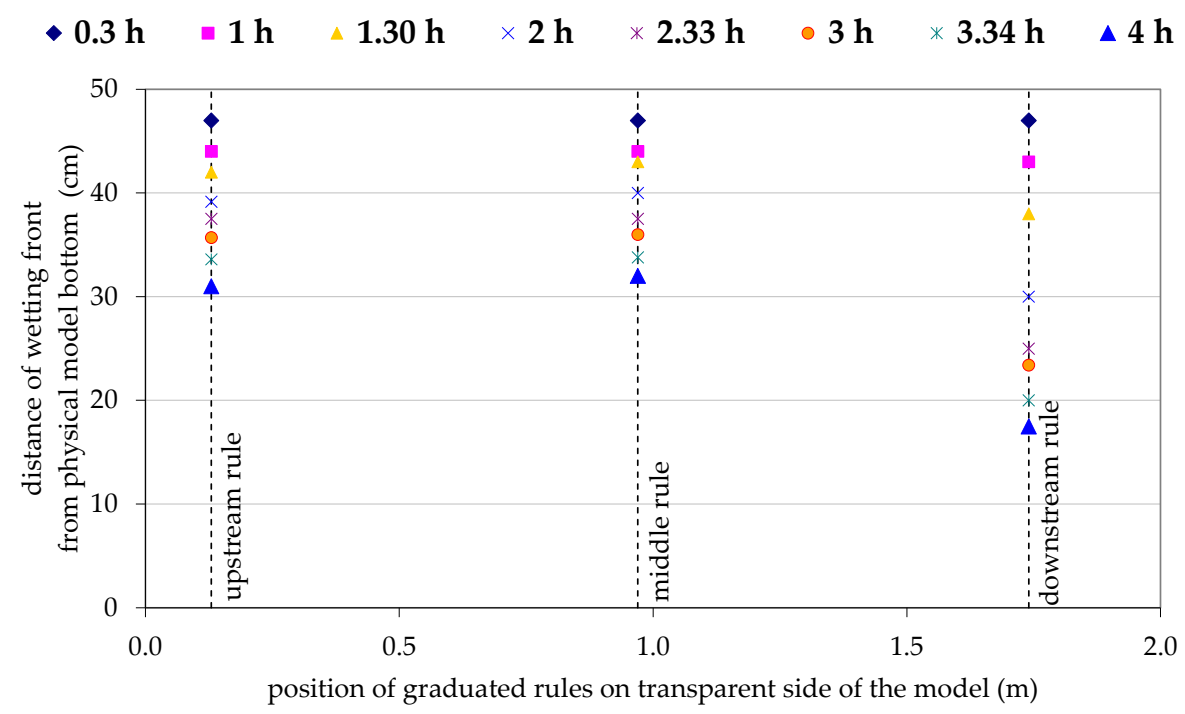

Figure 8. Time position of the wetting front, returned by its tracing through visual readings on the three graduated rules (upstream, middle, downstream) on the transparent side of the physical model, during first artificial rainfall.

After $48 \mathrm{~h}$ from the beginning of the first rainfall event, a second artificial rainfall was started at the same intensity $(15 \mathrm{~mm} / \mathrm{h})$ and duration $(4 \mathrm{~h})$ of the first one. Figure 9 shows, for the entire duration of the artificial rainfall events, the matric suctions measured by the tensiometer connected to 1, 2, 3, and 4, whose positions are shown in the photo in Figure 5.

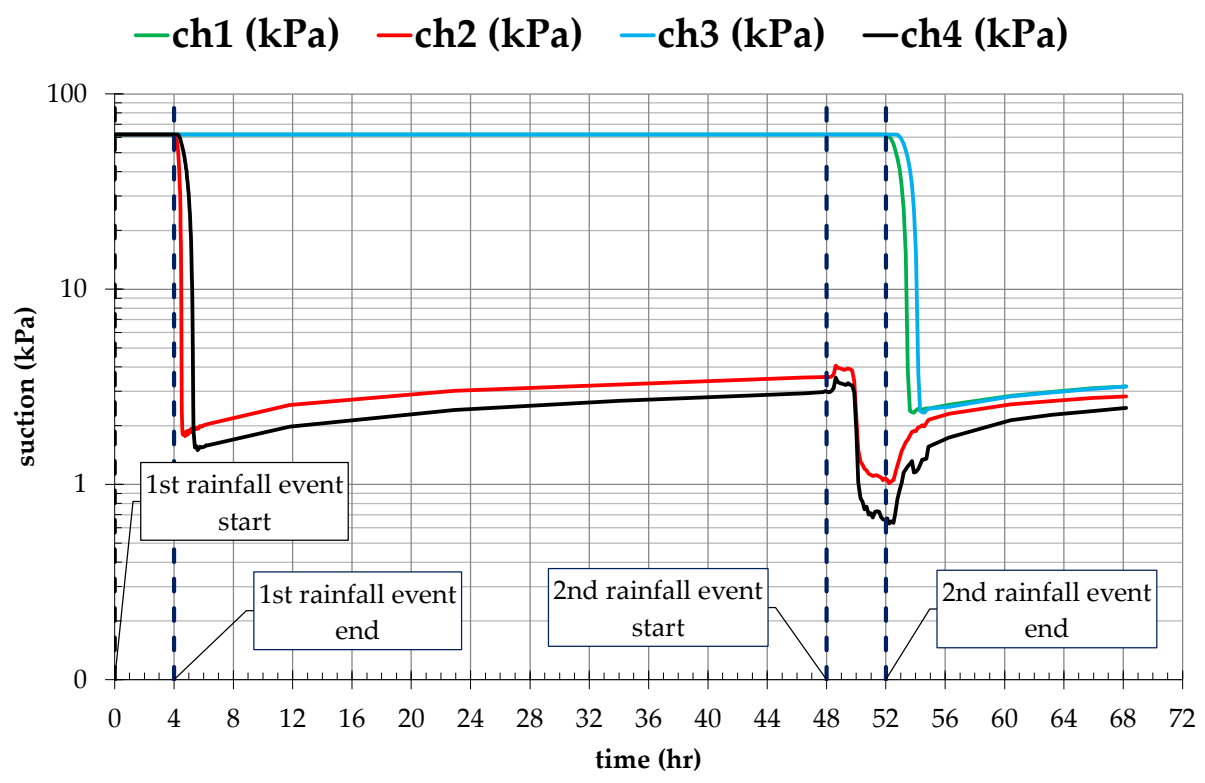

Figure 9. Logged time matric suction values at the four points of monitoring during the two infiltration stages. Labels mark the start/end time of the two main rainfall events.

The readings plotted in Figures 8 and 9 indicate that the advancing wetting front between the upstream and middle monitored verticals was observed to be almost parallel to the upper surface of the model, whereas it was found to become convex downstream, suggesting that the penetration rate of the wetting front was higher in the downstream portion of the model. Such observation is compatible with the occurrence of a plane seepage domain in the model, within which the flow rate components are influenced not only by the inclination of the model but also by the free drainage condition at the downstream lateral boundary. 
The sharp decrease of the matric suctions detected by both sensors 2 and 4 appears to correspond exactly to the arrival of the wetting front recorded through the visual inspection, as shown in Figure 8 (see blue triangles).

Figure 9 also shows the evolution of suction with time due to the second rainfall event, which started exactly $48 \mathrm{~h}$ after the end of the previous one. The plot clearly shows the final time of the second imbibition stage and the following suction drop at both sensors 1 and 3 (Figure 8), consequent to the imbibition of a deeper portion of the soil stratum. After the second rainfall event, further rainfall stages were applied until the complete imbibition of the soil stratum. The suction drops confirm that the imbibition of the downstream portion of the soil stratum, either at shallow depth or at large depth, always anticipates the imbibition of the upstream portion of the stratum.

Undisturbed samples were taken by means of a sample ring kit at locations comparable to those where the ceramic tips of the tensiometers had been installed. For these samples, the soil state was measured in order to assess the effect of imbibition of the soil porosity and fabric. In particular, the measured final average void ratio has been found equal to $e_{f}=0.68$ that, compared to the initial average void ratio $e_{i}=0.81$ (Table 2), denotes an appreciable reduction in soil porosity $\Delta e=-\left(e_{i}-e_{f}\right)=0.13$, as an effect of the wetting process. Such soil collapse will be discussed later.

As anticipated, a two-dimensional finite element inverse analysis (Figure 10) of the infiltration processes in the model was carried out based upon the data reported above.

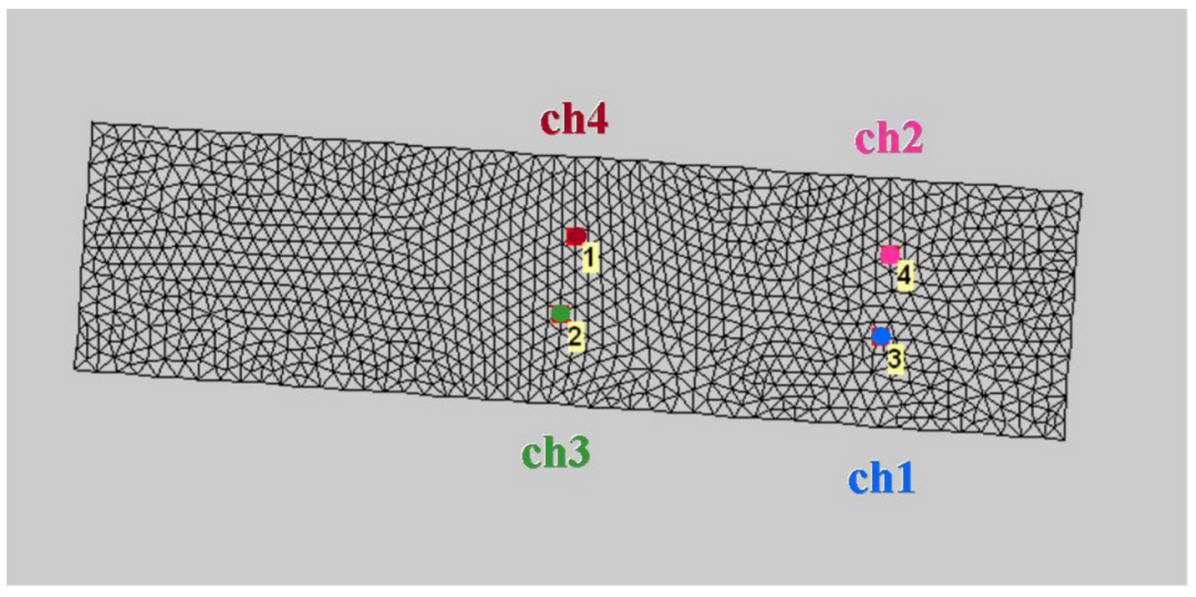

Figure 10. Mesh with unstructured discretization and observation nodes adopted in the inverse numerical analysis.

For both the water retention and the conductivity function, the Van GenuchtenMualem model [11,12] have been adopted:

$$
\begin{gathered}
\Theta=\frac{\theta-\theta_{r}}{\theta_{0}-\theta_{r}}=\left[\frac{1}{1+(\alpha s)^{n}}\right]^{m} ; \\
k(s)=k_{s} \Theta^{l}\left[1-\left(1-\Theta^{l / m}\right)^{m}\right]^{2} ;
\end{gathered}
$$

with:

$$
s>0 ; m=1-(1 / n) ; n>1 \text {. }
$$

This mathematical representation is usually employed for geotechnical engineering applications and its suitability to represent sandy soil behavior is generally recognized [32]. The parameters $\alpha, n$, and $l$ are shape factors connected to the water/air suction entry value, to the pore size distribution and to the pore tortuosity/connectivity, respectively. $\Theta$ is defined as the normalized water content in terms of volumetric water content, equal to unity as the current volumetric water content $\theta$ approaches the water content $\theta_{0}$ at which 
matric suction is zero. $\theta_{0}$ is assumed to be reached at the degree of saturation equal to $100 \%$, although this assumption is not necessarily true, as discussed in the Introduction.

In the first inverse-analysis (i.a.1), the soil's initial conditions, measured across the model as discussed before (Figures 2 and 6; Table 2) and corresponding to an average initial volumetric water content $\theta_{i}=0.021$ and matric suction $s_{i}=62 \mathrm{kPa}$ (blue triangle in Figure 11), were assigned to the numerical model.

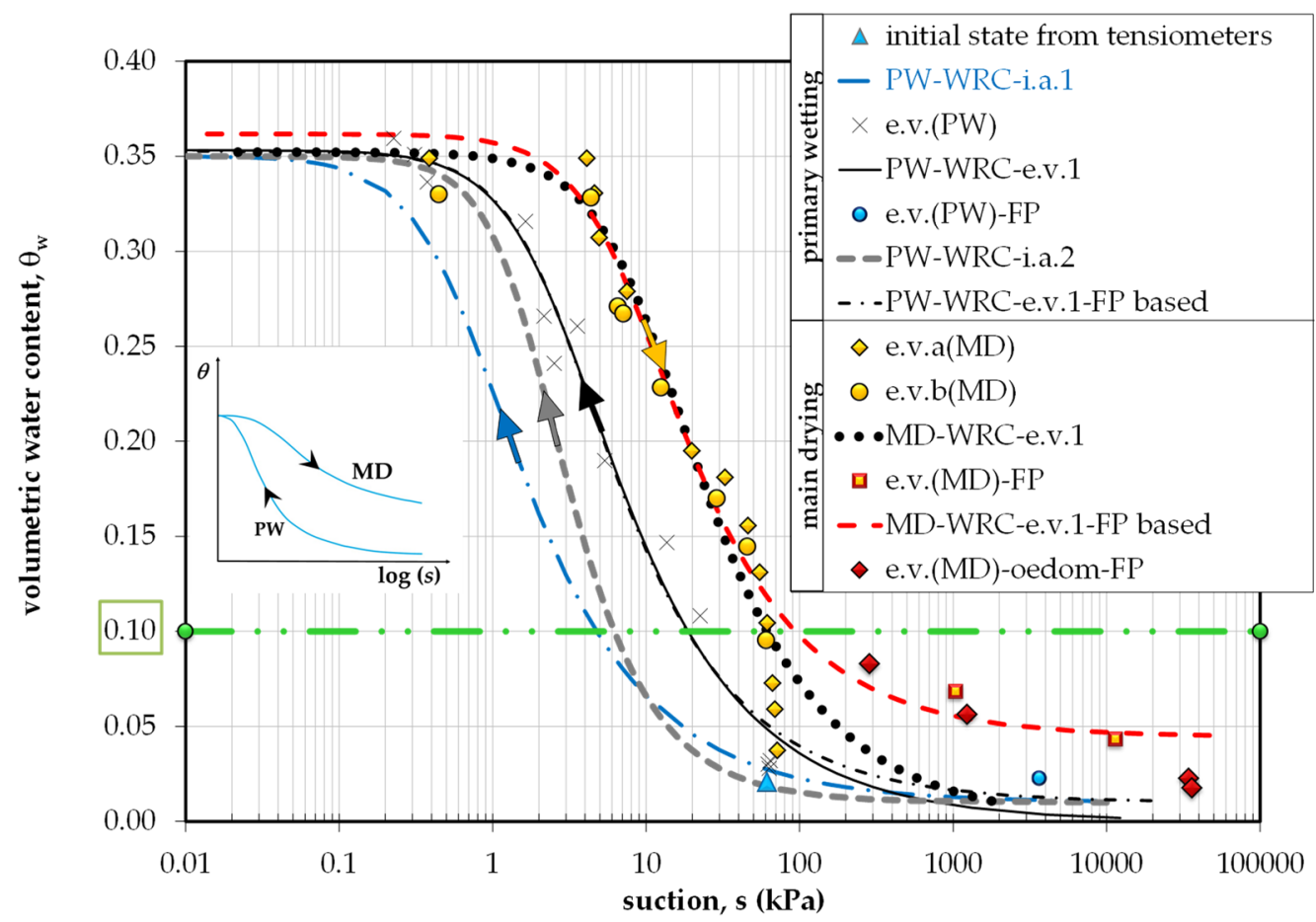

Figure 11. Experimental data from measurements and water retention functions from different estimate approaches. The inner plot shows the assigned hydraulic history.

The unknown's vector has been defined by the parameters $\left[\theta_{0} ; \alpha ; n ; k_{s}\right]$. This, therefore, does not solely include the shape factors $\theta_{r}$ and $l$, fixed to 0.01 and 0.5 , respectively, according to experimental results [4] and empirical evidence [12]. An optimization procedure has been implemented in the numerical inverse analysis by calibrating the fitting intervals of all the unknown shape parameters (Equation (1)) in order to match ranges of values expected for the soil class of the prototype soil, PS, and then refine such intervals to maximize the coefficient of determination $\mathrm{R} 2$. The best numerical result for the primary wetting water retention function, PW-WRC-i.a.1, was characterized by $\mathrm{R}^{2}=0.976$. PW-WRC-i.a.1 is represented by the blue dot-dashed line in Figure 11; the corresponding vector of the shape factors is reported in Table 3.

Table 3. Van Genuchten model shape factor of WRC, from different strategy/scale of investigation, hydraulic path: i.a. = inverse analysis/physical modeling; e.v. = element volume, on specimen measurement; $\mathrm{FP}=$ filter paper technique; $\mathrm{PW}=$ primary wetting; $\mathrm{MD}=$ main drying.

\begin{tabular}{cccccc}
\hline WRC & $\theta_{r}$ & $\theta_{\mathbf{0}}$ & $\boldsymbol{\alpha} \mathbf{( \mathbf { k P a } ^ { - 1 } )}$ & $\boldsymbol{n}$ & Strategy \\
\hline PW-WRC-i.a.1 & 0.01 & 0.350 & 1.590 & 1.645 & i.a. \\
PW-WRC-e.v.1 & 0.01 & 0.353 & 0.396 & 1.622 & e.v. \\
PW-WRC-ia2-FP based & 0.01 & 0.350 & 0.550 & 2.050 & i.a. \\
PW-WRC-e.v.1-FP based & 0.01 & 0.353 & 0.389 & 1.669 & e.v. \\
\hline MD-WRC-e.v.1 & 0.01 & 0.352 & 0.104 & 1.668 & e.v. \\
MD-WRC-e.v.1-FP based & 0.04 & 0.362 & 0.136 & 1.681 & e.v. \\
\hline
\end{tabular}


In the i.a.1 unknown vector, it is also included the saturated hydraulic conductivity $k_{s}$, found to result equal to $k_{s}=1.58 \times 10^{-6} \mathrm{~m} / \mathrm{s}$, a value consistent with the average value measured by means of permeameter tests in the laboratory on PS soil specimens of the same initial state as that recorded in the physical model, $k_{s}=1.2 \times 10^{-6} \mathrm{~m} / \mathrm{s}$.

\subsection{Soil Volumetric Collapse under Wetting}

The volumetric water content at zero suction, $\theta_{0}=0.350$, deduced through numerical analysis, is lower than that which would correspond to the initial porosity $n_{i}=0.45$ (Table 2) if the soil skeleton was rigid during wetting and was fully saturated at zero suction. Such a difference could be the effect of either a wetting collapse reducing the porosity or of a saturation degree lower than $100 \%$ at null suction, although the two causes may act together. For the investigated soil, it is plausible to have wetting behavior "left of intermediate", as defined in the Introduction (Figure 1), but there is also evidence of the occurrence of a wetting collapse upon wetting since the soil has experienced an irreversible volumetric collapse, that undisturbed samples collected by a sample ring kit allowed to estimate to be on average equal to $\Delta e=0.13$. This collapse is consistent with the soil's initial state, based on its standard Proctor compaction curve (Figure 4). The investigated prototype soil has then exhibited a volume decrease related to an increase in water content; this behavior places it in the category of collapsible soil [33]. The soil collapse upon wetting arises primarily from the reduction of the matric suction, starting far from saturation [8-10]. The phenomenon of collapse, along with that of the air-entrapment [34], explains why the volumetric water content at zero suction, $\theta_{0}$, is lower than the expected one, $n_{i}$, that is assumed generally as the value of this Van Genuchten shape factor, which may lead for this class of material, to the inadequate formulation of the WRC.

\subsection{Wetting Branch of WRC Deduced through Element Testing}

Through tests carried out using the experimental equipment (Figure 7a,b) shown and described above, several step-by-step wetting paths with distilled water have been conducted for assessments of soil PS. Element volume retention data could then be collected for different specimens, which are plotted as e.v.(PW) (cross plot in Figure 11). Volumetric collapse was also observed during the element volume primary wetting. The corresponding porosity reduction experienced by the specimens with the imbibition process (recorded at the end of the tests), has been on average, equal to $\Delta e=0.25$ slightly higher than for the soil buried in the physical model. The observed volumetric water contents at zero suction were on average equal to 0.36 lower than that corresponding to full saturation. This evidence suggests that this well-graded mixed soil reaches zero suction at saturation degrees lower than $100 \%\left(\theta_{0}<\theta_{S}\right.$; see Figure 2$)$.

Figure 12 shows the effect on volume collapse of the number of steps adopted for the imbibition stage.

The e.v.1(PW) and e.v.2(PW) refer to the specimens wetted until the suction was zeroed through a higher and a lower number of imbibition steps, respectively (circles and triangles in the plot). The data shows that the PS soil experiences a lower volumetric collapse the lower are the number of wetting steps, suggesting that the phenomenon of air-entrapment prevails when the imbibition occurs less gradually. This behavior is probably related to different evolution of the pattern of menisci within the soil during wetting and, thus, to different slippage of the particles, requires further experimental data and microstructural investigations to be generalized.

The complete set of retention data at element volume scale, measured by means of the experimental device, collected as e.v.(PW) in the plot of Figure 11 and interpolated by van Genuchten model through the code RETC [35], provides the primary wetting retention curve PW-WRC-e.v.1 (Figure 11), whose shape parameters are reported in Table 3.

The two primary wetting retention curves, although obtained by different approaches, are very similar, with a difference rather contained, in the air entry value. 


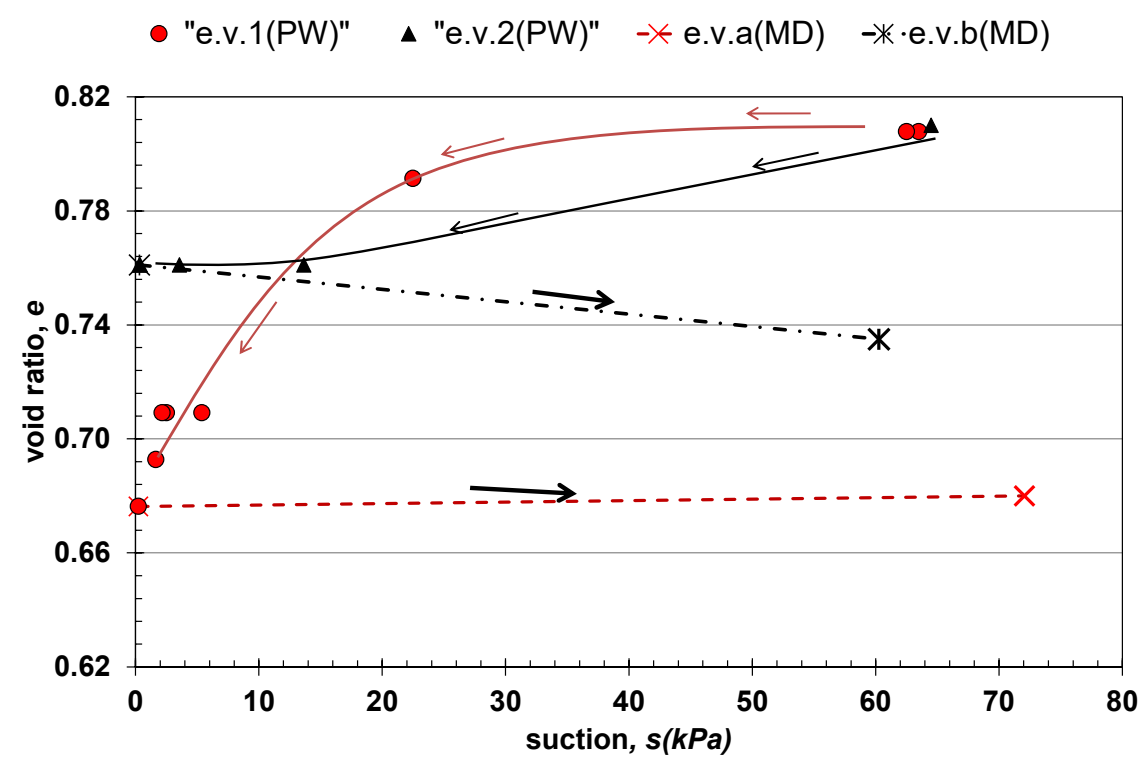

Figure 12. Reduction of void ratio, recorded by means of the experimental device for two specimens (e.v.1; e.v.2) subjected to a cycle of wetting (left arrows) and drying (right arrows).

\section{Shrinkage under Drying and Hydraulic Hysteresis}

\subsection{Experimental Determination of the Drying Branch of WRC}

The agreement between the primary wetting retention behavior observed at the element volume scale and that inferred by inverse analysis of the infiltration process within the physical model corroborated the reliability of the device designed for on-sample direct attainments of water retention data. The device has been then adopted to measure the drying branch of the WRC and to observe the soil's hysteretic features. In the present study, the hysteresis is triggered by a loop of primary wetting-main drying sequence, that is, a hydraulic history of interest for several earthworks.

Specimen weight, total volume, and suction were monitored during desorption induced by a procedure $[4,31]$ entailing consecutive stages during which the soil specimen, inside the device deprived of the caps, was left to desaturate by only free evaporation, for the time needed to achieve target weight reductions. At the end of each of these stages, the device was closed by the caps to hang evaporation and then allowing a uniform redistribution of the specimen's internal moisture. Finally, the matrix suction at the state so reached was acquired by a pair of minitesiometers. The logged experimental data are reported as series e.v.a(MD); e.v.b(MD) in Figure 11, and their interpolation by van Genuchten model using the code RETC provides the MD-WRC-e.v.1 (black dot line in Figure 11) whose shape parameters are reported in Table 3. The upper part of the data is indicative of a parallelism between the drying and the wetting transition branches and of a hysteresis loop of a magnitude consistent with that observed for soils of similar grain size [34]. Nevertheless, the data with volumetric water content less than $\theta_{\mathrm{w}}=0.1$, in Figure 11 below the green dash-dot-dot line, are almost on a vertical line, so causing the loss of parallelism of the lowest branch of the main drying water retention data e.v.a/b(MD) with those of primary wetting e.v.(PW). This anomaly in the shape of the hysteresis loop, before questioning the suitability of the Van Genuchten model for the specific pore size distribution of the tested soil under water uptake conditions, deserves further investigations of the two-state parameters mostly affected by measurement uncertainty, i.e., the matric suction and the volumetric strain. In particular, such groups of data with their sub-vertical arrangement, seem to reveal, on drying, a sort of suction cut-off at almost $70 \mathrm{kPa}$. This value, however, is quite far from the maximum measurable matric suction $(\cong 90 \mathrm{kPa})$ by a mini-tensiometer [36].

As an example, Figure 13a reports a matric suction value of $90 \mathrm{kPa}$ measured by a mini-tensiometer on a quite uniform sand specimen (Cotecchia et al., in prep.), whose 
matric suction, based on the granulometry (Figure 13b), is expected to depend only on capillarity.

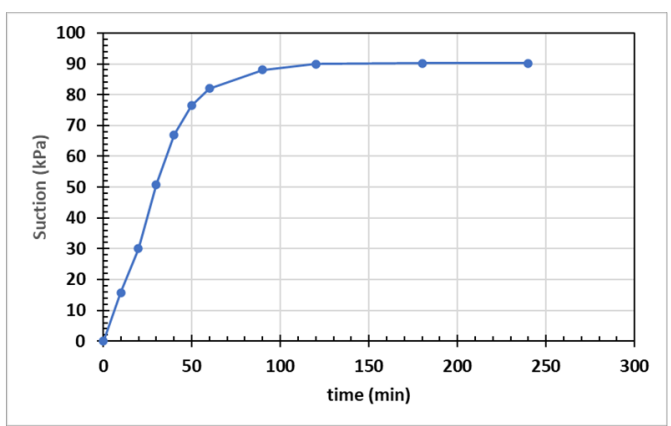

(a)

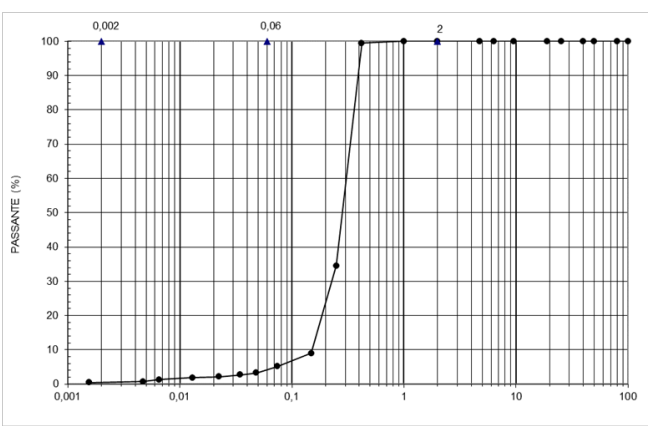

(b)

Figure 13. Example of suction measurement with $2100 \mathrm{~F}$ remote tensiometers on an unsaturated specimen of a sand: (a) mini-tensiometer measurement versus elapsed time during matric suction equalization; (b) grain size distribution.

Therefore, the above-mentioned matric suction cut-off of $70 \mathrm{kPa}$ should be more properly interpreted as an upper limit of the capillary component of the matric suction for this specific soil, revealing that these mini-tensiometers cannot "feel" the short-range adsorption component. To overcome the problems of the mini-tensiometer, relating both to their low-capacity measurement and its unsuitableness when matric suction arises also from short-range adsorption effects, the experimental investigations continued adopting the approach of joining branches of the WRC inferred by different experimental methods [37]. Attempts of direct measurements by Imperial College high capacity tensiometers [38] were made. The presence of an abundant sandy fraction prevented the required good contact between the tensiometer high-air entry disk and the soil specimen during the test, even using a kaolin paste as the interface between them to improve the contact condition, the cavitation of the tensiometer always occurred before equalization was achieved.

Matric suction measurements by means of the i.c.f.p.m. were then performed. For this purpose, sets of Whatman $\mathrm{N}^{\circ} 42$ filter paper discs were used, according to the setup and weighing prescriptions from $[39,40]$ and adopting equalization times, calibration curves (Equation (4), [41]) and data interpretation from recent literature ([39-41]).

Matric suction $\mathrm{s}(\mathrm{kPa}$,$) from i.c.f.p.m.:$

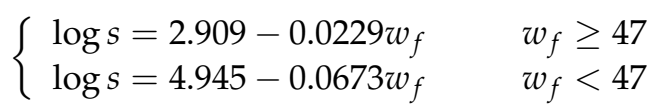

The design of the cap of the device (Figure 3) makes it possible at both ends to apply in contact two sets of filter paper. Each set consists of a main filter paper diskette sandwiched between other protective two, all with the same diameter $(55 \mathrm{~mm})$ and equivalent to that internal of the cell. In Figure 11, the data in legend denoted as "e.v.(PW)-FP" is a measurement corresponding to the initial state of the primary wetting, alternative to the initial state logged by means of the tensiometers. The data denoted as "e.v.(MD)-FP", instead, were collected during the main drying, at the end of the desaturation transition branch, at a very low degree of saturation. Each of these points comes from the average of measurements carried out at the ends of the cell, with the suction values being deduced according to calibration curves (Equation (4), [41]) The measured values (Table 4) are consistent with those reported by [42] for a soil of similar composition and state but resulting from different measurement techniques. 
Table 4. Retention data collected through i.c.f.p.m. at the bases of the sample hosted in the experimental device.

\begin{tabular}{ccc}
\hline Data Set & Volumetric Water Content $\boldsymbol{\theta}_{\mathbf{w}}$ & $\begin{array}{c}\text { Average Matric Suction } \\
\mathbf{( k P a )}\end{array}$ \\
\hline e.v.(PW)-FP & $2.0 \%$ & 3663 \\
e.v.(MD)-FP & $6.8 \%$ & 1031 \\
e.v.(MD)-FP & $4.3 \%$ & 11,316 \\
\hline
\end{tabular}

If the data e.v.(PW)-FP is included among those collected during the first wetting stage of the physical model, the inverse analysis returns a new WRC, that in Figure 11 is plotted as a grey dotted line and labelled PW-WRC-ia2-FP based, while its shape parameters are shown in the Table 3. The same data e.v.(PW)-FP, but together with the data set e.v.(PW), provides the WRC identified in Figure 11 as PW-WRC-e.v.1-FP based and represented with a thin black dash-dotted line, whose parameters are collected in Table 3.

Implementing the data e.v.(MD)-FP with the e.v.a(MD) and e.v.b(MD) series depleted of the data below $\theta_{\mathrm{W}}=0.1$, a new WRC was deduced, the red dashed line labelled in Figure 11 as MD-WRC-e.v.1-FP based and described parametrically in Table 3.

The data in Table 4, from the filter paper technique, are however quite far from the beginning of the suction cut-off on drying, mentioned before, due to the difficulties of using i.c.f.p.t. at the intermediate state as those experienced by the soil along the transition branch. This shortcoming was addressed with further measurements and setup measurements detailed below.

\subsection{Shrinkage during Drying Stages in Oedometer Apparatus}

During the water uptake stages performed through the device, the prototype soil exhibited volumetric shrinkage (Figure 12), negligible for the specimen e.v.a(MD), whereas it was rather low for the specimen e.v.b(MD). In this context, it is interesting to note that the finer component (S1, Figure 3) of the mixed soil is characterized by in situ shrinkage during the natural drying occurring seasonally, marked enough to make it susceptible to erosion [25]. Authors [43,44] demonstrated that for residual soils with a low coefficient of permeability and high shrinkage potential, how mixing with coarse-grained materials reduces the shrinkage potential. In the light of these literature observations, to better understand to what extent S2 inhibits the shrinkage potential of S1, a series of specimens (56 $\mathrm{mm}$ diameter, $20 \mathrm{~mm}$ height) of the prototype soil, with the same initial state condition as recorded for the physical model, were subjected in oedometer cells to imbibition/desiccation sequences. This was also needed because the device's ability to detect small volumetric shrinkage is questionable due to the inhibitory effect of the soil-perspex friction along the specimen's lateral surface. Each test was made up of three subsequent stages. The first consisted of applying a vertical load to reach an appropriate value of the confining vertical stress. The following stage was an imbibition, by gradually filling the oedometer cell with distilled water until the specimen achieved a full saturation state. The third stage entailed the cell water around the specimen extraction by means of a bent, thin tube (a syphon), thereby triggering the soil drying at lab standard hygrothermal conditions. The specimen height was monitored by a conventional linear displacement transducer and the stabilization of the readings was assumed as an indicator of the end of the relative stage. Seven tests were performed to study the effect of the net vertical stress on the amount of collapse, adopting values of $0,3.63,7.25 \mathrm{kPa}$, to reproduce the initial confinement conditions of the soil layer settled in the tank at the surface, at mid-height (25 cm deep) and at the bottom (50 cm deep), respectively. Each specimen was created at the same initial conditions, in terms of void ratio and volumetric water content, as the prototype soil at the beginning of the physical modeling (Table 2) and presumably at the same initial matric suction. The specimens were wetted from the top and the expected volumetric collapses were recorded. Figure 14 shows the settlements with time, in terms of void ratio, during the $24 \mathrm{~h}$ followed to the inundation. 


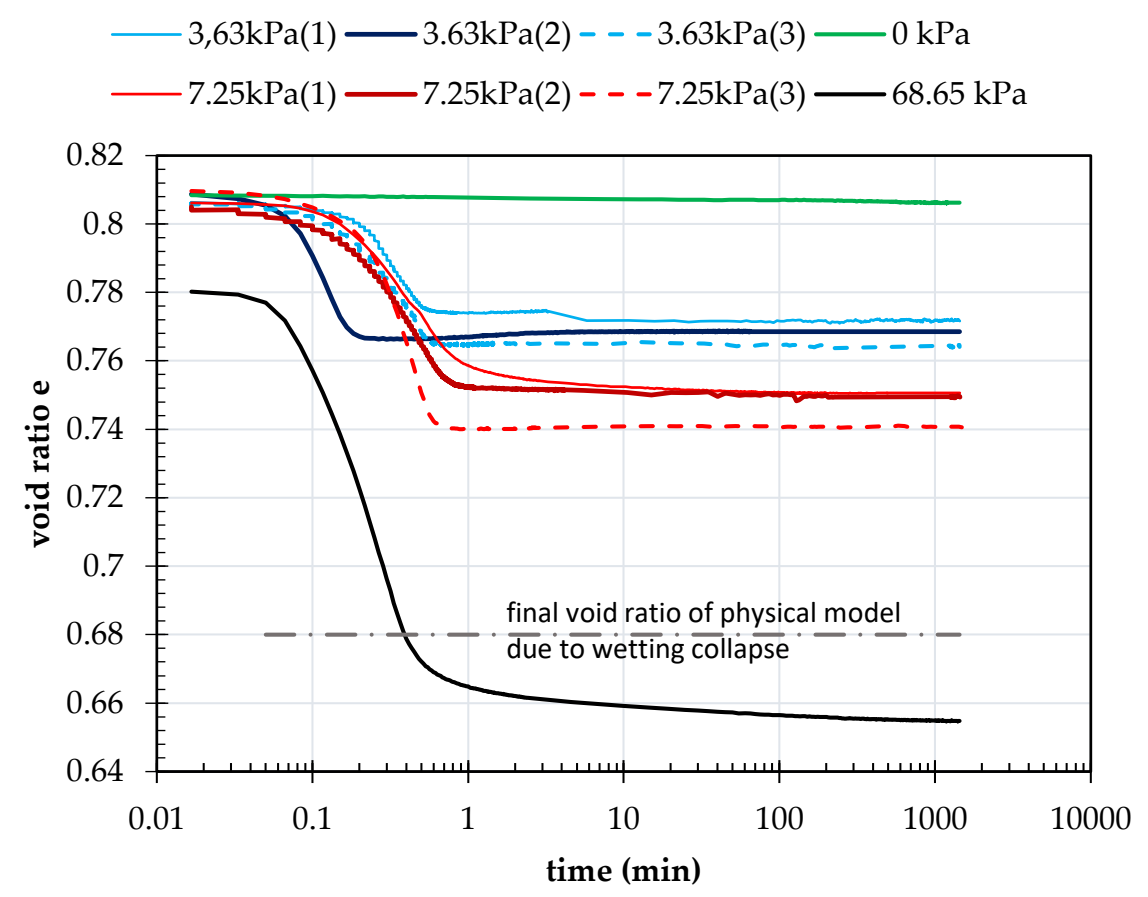

Figure 14. The time reduction of void ratio due to collapse observed during imbibition tests carried out on oedometric specimens of prototype soil at the same initial state condition of the physical model and confined with different vertical stress.

The volumetric collapse, for the same initial state conditions, increased as the applied vertical load increased, in agreement with observations on similar collapsible soils presented in the paper [45]. The observed collapse times were similar, within the first minute and some differences, as in the $3.63 \mathrm{kPa}(2)$ specimen, the faster in collapse, are due to the manual procedure adopted for the specimen's inundation stage. It was also noted that to reproduce the same void ratio reduction close to that observed in the physical model (represented by the dashed line in Figure 14), it has been necessary to increase the vertical load up to $68.65 \mathrm{kPa}$. In this respect, a different incidence of the end effects for the tank and the oedometer cell could be hypothesized. As explained above, these tests were followed by water uptake stages. The two specimens, $3.63 \mathrm{kPa}(2)$ and $7.25 \mathrm{kPa}(2)$ (Figure 14) were allowed to dry until the displacement transducer reached a stable reading. A second pair formed by the two specimens $3.63 \mathrm{kPa}(1)$ and $7.25 \mathrm{kPa}(3)$ (Figure 14), thanks to the information deduced by the first two, was allowed to dry until the volumetric water content reached values $\theta_{\mathrm{w}} \leq 0.1$, where the direct suction measurements carried out during drying in the device looked to lie on a not certificate instrumental limit.

Figure 15 shows the volumetric shrinkages observed with time on these four specimens: it can be observed that for the first pair of specimens, the void ratio reduction, although modest, is more significant than that recorded in the device (Figure 12). It can be reasonably assumed that in the device, this soil volumetric withdrawal caused the loss of full contact between the ceramic tip of the tensiometer and the soil, thus contributing to compromise, together with the short-range adsorption phenomena, the ability of the Soilmoisture sensors to correctly detect the matric suction below a water content threshold. 


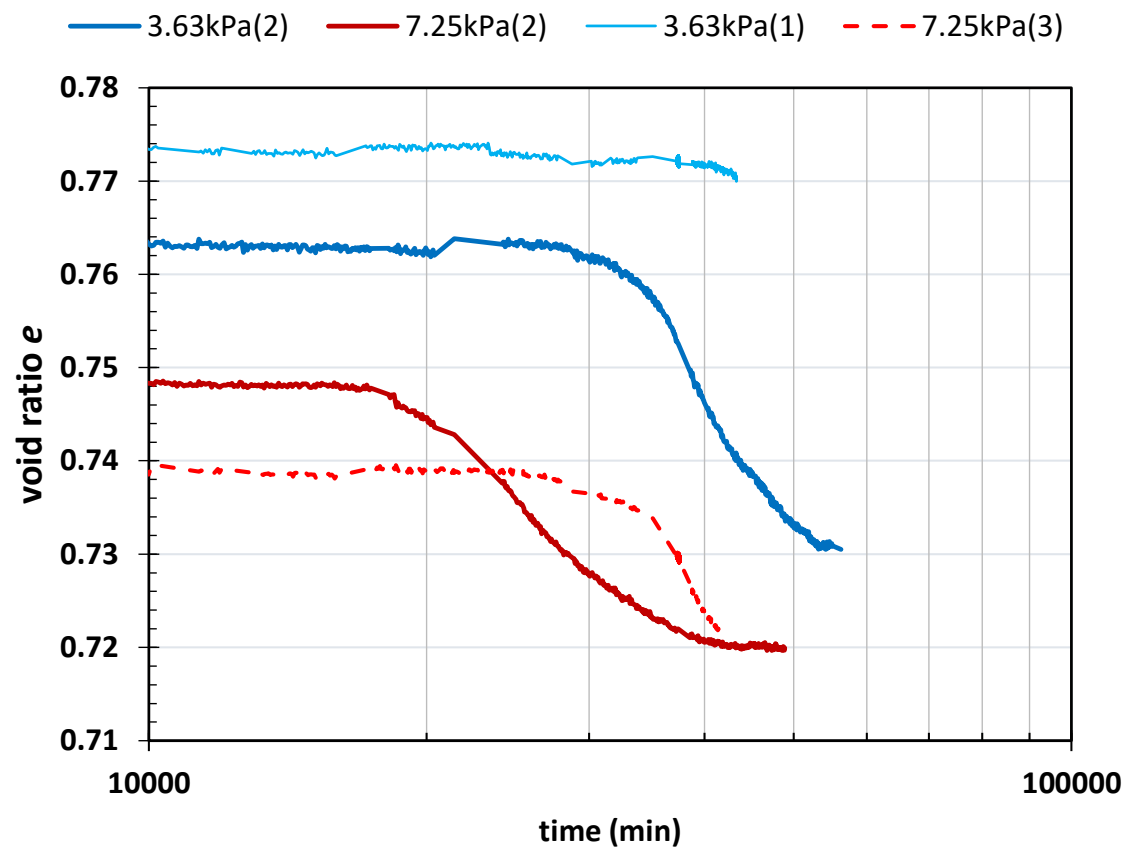

Figure 15. Volumetric shrinkage observed over time on a selected group of samples among those subjected to imbibition tests.

These four tests were completed by i.c.f.p.t. measurements, adopting the same procedures followed for the samples in the device. At the two bases of each specimen were applied a set of three Whatman 42 filter paper $55 \mathrm{~mm}$ discs. Table 5 reports the resulting matric suction values inferred by Equation (4) from [44]:

Table 5. Matric suction from i.c.f.p.m. at the volumetric water content at the end state of drying stages of shown in Figure 14.

\begin{tabular}{cccc}
\hline Specimen & $\theta_{\mathbf{w}}$ & $\begin{array}{c}\text { Matric Suction at Top Base } \\
\mathbf{( k P a )}\end{array}$ & $\begin{array}{c}\text { Matric Suction at Bottom } \\
\text { Base (kPa) }\end{array}$ \\
\hline $7.25 \mathrm{kPa}(3)$ & $8.30 \%$ & 282 & 267 \\
\hline $3.63 \mathrm{kPa}(1)$ & $5.64 \%$ & 1234 & 1192 \\
\hline $7.25 \mathrm{kPa}(2)$ & $2.27 \%$ & 34,228 & 33,866 \\
\hline $3.63 \mathrm{kPa}(2)$ & $1.77 \%$ & 35,932 & 34,136 \\
\hline
\end{tabular}

The matric suction recorded for the samples " $7.25 \mathrm{kPa}(3)$ " and " $3.63 \mathrm{kPa}(1)$ " were significantly higher than those recorded by the mini tensiometers for similar volumetric water content. The matric suction of the samples " $7.25 \mathrm{kPa}(2)$ " and " $3.63 \mathrm{kPa}(2)$ " were consistent with those acquired with the same technique but through the element-volume device: points "e.v.(MD)-FP" in Figure 11. This group of four data is plotted in Figure 11 with a series of red diamonds labelled as "e.v.(MD)-oedom-FP", and they seem to be in perfect agreement with the trend of the terminal branch of "MD-WRC-FP-based".

To investigate the difference between total and matric suction, especially at the lowest degrees of saturation for which, although in contact, the filter paper method only measures total suction $[41,46]$, three oedometric shaped specimens were subjected to simultaneous measurements with i.c.f.p.m. and with n.i.c.f.p.m., applying Whatman 42 filter paper discs in contact to the lower base and not in contact to the upper base, by interposing a rubber o-ring between the disc and the top of the specimen. For the n.i.c.f.p.m. the total suction values were inferred by the Equation (5) from [41]: 
Total suction $\psi(\mathrm{kPa})$, from n.i.c.f.p.m.:

$$
\left\{\begin{array}{cc}
\log s=8.778-0.0222 w_{f} & w_{f} \geq 47 \\
\log s=5.31-0.0879 w_{f} & w_{f}<47
\end{array}\right.
$$

The specimens reconstituted at the same initial state of the physical model were first wetted by the usual imbibition procedure adopted in this work, and before applying the filter paper discs as described above, they were left to dry differently from each other. Table 6 shows the values of suction from i.c.f.p.m. and n.i.c.f.p.m., and so, supposedly of matric and total suction, respectively.

Table 6. Suction values inferred by i.c.f.p.m. and n.i.c.f.p.m., on three oedometric shaped specimens, adopting calibration curve (Equations (4) and (5), from [41]) for Whatman $\mathrm{N}^{\circ} 42$ filter paper.

\begin{tabular}{cccc}
\hline Specimen & $\theta_{\mathbf{w}}$ & $\begin{array}{c}\text { Total Suction at Top Base } \\
\mathbf{( k P a )}\end{array}$ & $\begin{array}{c}\text { Matric Suction at Bottom } \\
\text { Base (kPa) }\end{array}$ \\
\hline 1 & $4.08 \%$ & 12,811 & 8669 \\
\hline 2 & $4.82 \%$ & 6880 & 5895 \\
\hline 3 & $5.07 \%$ & 4741 & 4470 \\
\hline
\end{tabular}

The differences among total and matric suctions presented in the table could be interpreted either as errors, expected to be $10 \%$ from the use of [41] equations, or as osmotic suction, depending on the pore fluid composition. This aspect will require further investigation on the salt concentration in the pore water of this soil.

\section{Conclusions}

An experimental investigation carried out at two different scales, i.e., on a physical model and on element volume, has allowed to depict the hydraulic behavior of a wellgraded mixed soil upon both wetting and drying. The tests have revealed that measuring the matric suction of this kind of soil by using mini-tensiometers is not enough to obtain reliable values when the water content is low, because the short-range component of the matric suction seems not detectable by this sensor. Measurements with filter paper tests have helped the definition of the soil retention properties and the loop of hysteresis over a wide suction range, making the inverse numerical analysis of the infiltration process more successful. The filter papers have been employed to measure both the matrix and the total suction, whose discrepancy lies within the range of error for this measurement technique and, thus, cannot be attributed to the osmotic component without information on the pore water salinity. It has been pointed out that the soil of reference here lies in the hydraulic class of the porous materials for which the suction disappears, on the wetting path, for saturation degree lower than $100 \%$. It was not obvious a priori for a "mediumgrained" mixed soil like the tested one. The wetting collapse has been found to be of a different magnitude for almost equal stress state conditions, depending on the scale of investigation, as the possible effect of the different boundary interactions. This collapse seems to be, in any case, a function of the vertical confining stress. Finally, the shrinkage during drying, due to the finer fraction of the soil, has been appreciated by the tests carried out in oedometer apparatus, whereas in the physical model and in the cylindrical perspex device this detection has been a difficult task.

Author Contributions: Conceptualization, O.B., F.C. (Francesco Cafaro) and F.C. (Federica Cotecchia); methodology, O.B., F.C. (Francesco Cafaro) and F.C. (Federica Cotecchia); validation, F.C. (Francesco Cafaro) and F.C. (Federica Cotecchia); investigation, O.B. and F.C. (Francesco Cafaro); resources, O.B., F.C. (Francesco Cafaro) and F.C. (Federica Cotecchia); data curation, O.B.; writing-original draft preparation, O.B. and F.C. (Francesco Cafaro); writing-review and editing, O.B., F.C. (Francesco Cafaro) and F.C. (Federica Cotecchia); visualization, O.B. and F.C. (Francesco Cafaro); supervision, F.C (Federica Cotecchia). All authors have read and agreed to the published version of the manuscript. 
Funding: This research received no external funding.

Data Availability Statement: Not applicable.

Conflicts of Interest: The authors declare no conflict of interest.

\section{References}

1. Aitchison, G.D. Engineering concepts of moisture equilibria and moisture changes in soils. Statement of the Review Panel. In Moisture Equilibria and Moisture Changes in Soils Beneath Covered Areas; A Symposium in Print, Butterworths: Sydney, Australia, 1964; pp. 7-21.

2. Zhai, Q.; Rahardjo, H.; Satyanaga, A. Estimation of the air permeability function from the soil-water characteristic curve. Can. Geotech. J. 2019, 56, 505-513. [CrossRef]

3. Lu, N.; Likos, W.J. Suction stress characteristic curve for unsaturated soil. J. Geotech. Geoenviron. Eng. 2006, 132, 131-142. [CrossRef]

4. Cafaro, F.; Hoffmann, C.; Cotecchia, F.; Buscemi, A.; Bottiglieri, O.; Tarantino, A. Modellazione del comportamento idraulico di terreni parzialmente saturi a grana media e grossa. Riv. Ital. Di Geotec. 2008, 3, 54-72.

5. Kodesová, R. Determination of Hydraulic Properties of Unsaturated Soil via Inverse Modeling; Lecture Given at the College on Soil Physics: Trieste, Italy, 2003.

6. Richards, L.A. Capillary conduction of liquids through porous media. Physics 1931, 1, 318-333. [CrossRef]

7. Luckner, L.; Van Genuchten, M.T.; Nielsen, D.R. A consistent set of parametric models for the two-phase flow of immiscible fluids in the subsurface. Water Resour. Res. 1989, 25, 2187-2193. [CrossRef]

8. Vilar, O.M. Suction controlled oedometer tests on compacted clay. In Unsaturated Soils: Proceedings of the 1st International Conference on Unsaturated Soils, Paris, France, 6-8 September1995; Alonso, E.E., Delage, P., Eds.; Balkema: Rotterdam, The Netherlands, 1995; Volume 1, pp. 201-206.

9. Tadepalli, R.; Fredlund, D.G. The Collapse Behavior of a Compacted Soil During Inundation. Can. Geotech. J. 1991, 28, 477-488. [CrossRef]

10. Rodrigues, R.A.; Vilar, O.M. Relationship between collapse and soil-water retention curve of a sandy soil. In Proceedings of the 4th International Conference on Unsaturated Soils, Carefree, AZ, USA, 2-6 April 2006; Volume 1, pp. $1025-1036$.

11. van Genuchten, M.T. A closed form equation for predicting the hydraulic conductivity of unsaturated soils. Soil Sci. Soc. Am. J. 1980, 44, 892-898. [CrossRef]

12. Mualem, Y. A new model for predicting the hydraulic conductivity of unsaturated porous media. Water Resour. Res. 1976, 12, 513-522. [CrossRef]

13. Burdine, N.T. Relative permeability calculation from pore size distribution data. Trans. Am. Inst. Min. Eng. 1953, 198, 71-78. [CrossRef]

14. Fatt, I.; Dykstra, H. Relative permeability studies. Trans. Am. Inst. Min. Eng. 1951, 192, 249-255. [CrossRef]

15. Touma, J. Comparison of the soil hydraulic conductivity predicted from its water retention expressed by the equation of Van Genuchten and different capillary models. Eur. J. Soil Sci. 2009, 60, 671-680. [CrossRef]

16. Sakellariou-Makrantonakia, M.; Angelaki, A.; Evangelides, C.; Bota, V.; Tsianou, E.; Floros, N. Experimental determination of hydraulic conductivity at unsaturated soil column. Procedia Eng. 2016, 162, 83-90. [CrossRef]

17. Federico, A.M.; Bottiglieri, O.; Cafaro, F.; Elia, G. Hydraulic Characterization of a Self-Weight Compacted Coal. Studia Geotech. Et Mech. 2020, 42, 48-60. [CrossRef]

18. Cafaro, F.; Cotecchia, F. Influence of the mechanical properties of consolidated clays on their water retention curve. Ital. Geotech. J. 2015, 2, 11-27.

19. Marzulli, V.; Cafaro, F.; Ziccarelli, M. Hydraulic characterization of a pervious concrete for deep draining trenches. J. Mater. Civ. Eng. 2018, 30, 04018100. [CrossRef]

20. Hopmans, J.W.; Dane, J.H. Thermal conductivity of two porous media as a function of water content, temperature, and density. Soil Sci. 1986, 142, 187-195. [CrossRef]

21. Stauffer, F.; Kinzelbach, W. Cyclic hysteretic flow in porous medium column: Model, experiment, and simulations. J. Hydrol. 2001, 240, 264-275. [CrossRef]

22. Milatz, M.; Grabe, J. A New Simple Shear Apparatus and Testing Method for Unsaturated Sands. Geotech. Test. J. 2015, 38, 9-22. [CrossRef]

23. Pedone, G.; Tsiampousi, A.; Cotechia, F.; Zdravkovic, L. Coupled hydro-mechanical modelling of soil-vegetation-atmosphere interaction in natural clay slopes. Can. Geotech. J. 2021. [CrossRef]

24. Leal-Vaca, J.C.; Gallegos-Fonseca, G.; Rojas-González, E. The decrease of the strength of unsaturated silty sand. Eng. Res. Technol. 2012, XIII, 393-402. [CrossRef]

25. Cotecchia, F.; Fratino, U.; Fanelli, L. Monitoring and modelling the erosion processes on the hillslopes of the Rendina lake. In Proceedings of the Ninth International Symposium on River Sedimentation (Volume IV), Yichang, China, 18-21 October 2004; pp. 2243-2251, ISBN 7-302-09684-8.

26. Levenberg, K. A method for the solution of certain nonlinear problems in least squares. Q. Appl. Math. 1944, 2, 164-168. [CrossRef]

27. Marquardt, D.W. An algorithm for least-squares estimation of nonlinear parameters. SIAM 1963, 11, 431-441. [CrossRef] 
28. Cassel, D.K.; Klute, A. Water Potential: Tensiometry. In Methods of Soil Analysis, Part 1; American Society of Agronomy: Madison, WI, USA, 1986; pp. 563-596.

29. Simunek, J.; Sejna, M.; van Genuchten, M. New features of version 3 of the HYDRUS (2D/3D) computer software package. J. Hydrol. Hydromech. 2018, 66, 133-142. [CrossRef]

30. Yu, C.; Zheng, C. HYDRUS: Software for Flow and Transport Modeling in Variably Saturated Media, Software Spotlight. Ground Water 2010, 48, 787-791. [CrossRef]

31. Bottiglieri, O. Caratterizzazione Idraulica di un Terreno a Grana Media Parzialmente Sa-turi. Ph.D. Thesis, Politecnico di Bari, Bari, Italy, 2009.

32. Leong, E.C.; Rahardjo, H. Review of Water Characteristic Curve Functions. Geotech. Geo-Environ. Eng. 1997, 123, 1106-1117. [CrossRef]

33. Dudley, J.H. Review of collapsing soils. J. Soil Mech. Found. Div. Proc. Am. Soc. Civ. Eng. 1970, 96, 925-947. [CrossRef]

34. Fredlund, D.C. Unsaturated soil mechanics in Engineering Practice. J. Geotech. Geoenviron. Eng. 2006, 132, 286-321. [CrossRef]

35. Van Genuchten, M.V.; Leij, F.J.; Yates, S.R. The RETC Code for Quantifying Hydraulic Functions of Unsaturated Soils; EPA/600/2-91/065, R.S.; U.S. Environmental Protection Agency: Ada, OK, USA, 1991; Volume 83.

36. Stannard, D.I. Tensiometers: Theory, construction, and use. Geotech. Test. J. 1992, 15, 48-58.

37. Bottiglieri, O.; Cafaro, F.; Cotecchia, F. Estimating the Retention Curve of a Compacted Soil through Different Testing and Interpretation Methods. In Unsaturated Soils: Research and Applications; Mancuso, C., Jommi, C., D'Onza, F., Eds.; Springer: Berlin/Heidelberg, Germany, 2012; pp. 47-54.

38. Ridley, A.M.; Burland, J.B. A new instrument for the measurement of soil moisture suction. Geotechnique 1993, 43, 321-324. [CrossRef]

39. Lu, N.; Likos, W.J. Unsaturated Soil Mechanics; John Wiley: Hoboken, NJ, USA, 2004; p. 556.

40. Marinho, F.A.M.; Oliveira, O.M. The Filter Paper Method Revisited. Geotech. Test. J. 2006, 29, $250-258$.

41. Leong, E.C.; He, L.; Rahardjo, H. Factors affecting the filter paper method for total and matric suction measurements. Geotech. Test. J. 2002, 25, 321-332.

42. Salager, S.; ElYoussoufi, M.S.; Saix, C. Definition and experimental determination of a soil-water retention surface. Can. Geotech. J. 2010, 47, 609-622. [CrossRef]

43. Indrawan, I.G.; Rahardjo, H.; Leong, E. Effects of coarse-grained materials on properties of residual soil. Eng. Geol. 2006, 82, 154-164. [CrossRef]

44. Henry, K.; Rahardjo, H.; Leong, E. Effects of different drying rates on shrinkage characteristics of a residual soil and soil mixtures. Eng. Geol. 2008, 102, 31-37. [CrossRef]

45. Li, P.; Vanapalli, S.; Li, T. Review of collapse triggering mechanism of collapsible soils due to wetting. J. Rock Mech. Geotech. Eng. 2016, 8, 256-274. [CrossRef]

46. Raadt, P.; Delwyn, F.; Clifton, A.W.; Klassen, M.J.; Jubien, W.E. Soil suction measurements at several sites in Western Canada. Transp. Res. Rec. 1987, 1137, 24-35. 